\title{
"Capacity building to implement state of the art surveillance systems for antibiotic consumption and resistance in kosovo": results of European Union research project in Kosovo
}

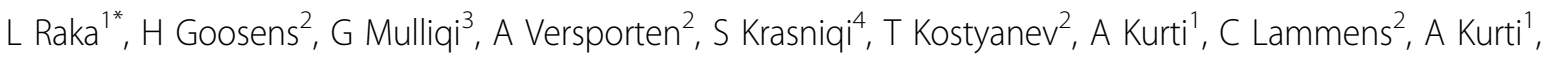 \\ F Paasch ${ }^{2}$, V Uka ${ }^{4}$, A Jakupi ${ }^{5}$, A Loku' ${ }^{4}$ D Raka ${ }^{4}$
}

From 3rd International Conference on Prevention and Infection Control (ICPIC 2015)

Geneva, Switzerland. 16-19 June 2015

\section{Introduction}

The project "Capacity building to implement state of the art surveillance systems for antibiotic consumption and resistance in Kosovo" was financed by the European Union and implemented by the National Institute of Public Health of Kosovo in collaboration with the University of Antwerp during 2012-2014.

\section{Objectives}

The main objectives of this project were to monitor volumes and patterns of antibiotic use and to establish a comprehensive surveillance system of antibiotic resistant bacteria.

\section{Methods}

Total antimicrobial use data were analysed according to the WHO ATC/DDD methodology and expressed in DDD/1000inhabitants/day (DID). Data on antimicrobial use in hospitals were collected in all seven hospitals of Kosovo using the methodology of a point prevalence survey based on ESAC. Survey of consumption in primary care was retrospective and involved 12 Family Medicine Centres covering all 6 regions of Kosova.

\section{Results}

Total antibacterial use in Kosovo was 26.3 DID. The top antibacterial subgroups were penicillins (12.8 DID, 48.7\% of all antibacterials) and other beta-lactam antibacterials (4.9 DID, 18.7\%). Kosovo had the highest proportional total parenteral use of cefriaxone in Europe (53.9) and lowest use of systemic antimycotics and antifungals (0.08 DID). Of total number of 1579 enrolled patients in Kosovo hospitals, 769 (48.7\%) of them received antibiotics. The most prescribed antibiotic was ceftriaxone (41.5\%), followed by gentamycin (12.1\%). Antibiotics were administered mainly through parenteral route (73.3\%). Empiric antibiotic prescription was higher than etiological $(88.28 \%$ vs. $11.72 \%)$. Of all patients who attended primary care level, 33\% received antibiotics. Administration through the parenteral route was $43 \%$. Antibiotic prescription with generic names was noticed only in $31 \%$ of cases. The most prescribed antibiotic in primary care level was also ceftriaxone.

\section{Conclusion}

Gathered data will serve as a tool for quality improvement in Kosovo and will support the preparation of guidelines and protocols for prudent use of antibiotics.

\section{Disclosure of interest}

None declared.

\section{Authors' details \\ ${ }^{1}$ National Institute of Public Health of Kosovo, Albania. ${ }^{2}$ University of Antwerp, Belgium. ${ }^{3}$ National Institute of Public Health of Kosovo, Prishtina. ${ }^{4}$ University of Prishtina. ${ }^{5}$ Kosovo Agency for Medical Products, Albania.}

Published: 16 June 2015

National Institute of Public Health of Kosovo, Albania

Full list of author information is available at the end of the article 
doi:10.1186/2047-2994-4-S1-P178

Cite this article as: Raka et al.: "Capacity building to implement state of

the art surveillance systems for antibiotic consumption and resistance

in kosovo": results of European Union research project in Kosovo.

Antimicrobial Resistance and Infection Control 2015 4(Suppl 1):P178.

Submit your next manuscript to BioMed Central and take full advantage of:

- Convenient online submission

- Thorough peer review

- No space constraints or color figure charges

- Immediate publication on acceptance

- Inclusion in PubMed, CAS, Scopus and Google Scholar

- Research which is freely available for redistribution

Submit your manuscript at www.biomedcentral.com/submit
C Biomed Central 